\title{
MOLECULAR DETECTION AND SEROPREVALENCE OF MYCOPLASMAS IN CLINICALY HEALTHY WORKING DOGS
}

\author{
Sara Suhadolc Scolten ${ }^{1}$, Nataša Tozon ${ }^{1}$, Saša Koprivec ${ }^{2}$, Kaja Felda $^{1}$, Mateja Florjančič ${ }^{1}$, Dušan Benčina†, Brigita Slavec ${ }^{1 *}$ \\ ${ }^{1}$ Veterinary Faculty, University of Ljubljana, Gerbičeva 60, 1000 Ljubljana, ${ }^{2}$ Department of Animal Science, Biotechnical Faculty, University of \\ Ljubljana, Groblje 3, 1230 Domžale, Slovenia; \\ ${ }^{*}$ Corresponding author, E-mail: brigita.slavec@vf.uni-lj.si
}

\begin{abstract}
In this study seroprevalence and prevalence of mycoplasmas in clinically healthy dogs were studied. Thirty-four working dogs of various breeds, gender and age were included in this research. Among them, 27 were working dogs from Slovene armed forces and 7 were working sheepdogs. We used dot-immunobinding assay (DIBA) as a serological test for the detection of specific antibodies to Mycoplasma cynos, Mycoplasma canis and Mycoplasma molare and consensus PCR for detection of genes for $16 \mathrm{~S}$ rRNA or $16 \mathrm{~S} / 23 \mathrm{~S}$ IGS region of mycoplasmas. Specific antibodies against at least one of the canine mycoplasmas were detected in $94.1 \%$ dogs. Of them $23.5 \%$ samples showed positive reaction only to $M$. cynos, $20.6 \%$ were positive only to $M$. canis and none of the samples were positive only to M. molare. Altogether $47.0 \%$ of samples were positive to M. cynos and M. canis whereas only one dog (2.9\%) had specific antibodies to all three mycoplasmas tested. The presence of mycoplasmas detected by PCR was $57.14 \%$ in younger dogs ( $\leq 1$ year) and $18.5 \%$ to $35.3 \%$ in older dogs, depending on year of the sampling. Genital swabs were PCR-positive in more cases (60\%) in comparison with oral swabs (46.7\%). M. canis was detected in $40 \%$ of positive cases, in the same percent of samples mixed not determined mycoplasma infections were confirmed. Mycoplasma species such as: M. cynos, M. edwardii, M. maculosum, M. spumanswere determined each in single cases and in one case mixed ureaplasma infection was confirmed.
\end{abstract}

Key words: working dogs; canine mycoplasmas; Mycoplasma canis, Mycoplasma cynos; DIBA; PCR

\section{Introduction}

Mycoplasmas are the smallest bacteria with the smallest number of genes that are still capable of self-replication. Some of them are pathogenic for humans and animals $(1,2)$. Up to now, 16 described mycoplasma species and two not fully described species have been isolated from dogs $(3,4)$. Mycoplasmas can be found in the upper respiratory tract of healthy dogs (5). Clinical studies have shown that they can be detected in

Received: 7 March 2017

Accepted for publication: 20 June 2017 the throat of every single healthy animal tested $(3,5)$. Based on different studies most pathogenic is $M$. cynos which is associated with canine infectious respiratory disease, frequent disease, especially in dog shelters $(6,7)$.

Some mycoplasmas can cause infections in different parts of the urinary and reproductive system. Most commonly M. canis was found, but also M. spumans, M. edwardii, M. cynos, M. molare and M. maculosum were isolated $(8,9)$. Canine mycoplasmas can be detected directly by culture or molecular methods and indirectly by serological methods. Culture is still the golden standard for the detection of mycoplasmas in 
samples, despite a long turnaround time and complex species determination that bring about an additional need for serological, biochemical or molecular testing. Compared to culture, molecular methods based on nucleic acid amplification tests such as PCR (polymerase chain reaction) are faster and easier for pathogen identification $(3,10)$. For detection of specific mycoplasma antibodies, serological methods are required such as enzyme immunoassays, immunofluorescence, agglutination tests and immunoblotting (7, $11,12,13)$. DIBA where mycoplasma cells are directly applied on the membrane can be used to detect specific antibodies (14). The aim of this study was to establish the prevalence of canine mycoplasmas especially those which are usually linked with clinical disease (M. cynos, $M$. canis) in clinically healthy working dogs in Slovenia. DIBA was used for simultaneous detection of specific antibody to 3 different canine mycoplasma species and consensus PCR was used for detection of the mycoplasma genomic DNA.

\section{Materials and methods}

\section{Animals and samples}

Thirty-four dogs of various breeds, gender and age were included in this research (Table 1). Among them, 27 were working dogs (aged between 2 to 10 years) from Slovene armed forces, stationed in the south-east part of Slovenia and 7 working sheepdogs (younger than 1 year), stationed on pastures in the south-west of Slovenia. Blood samples and swabs (oral, vaginal or preputial) were examined. The military working dogs were sampled in the years 2008 and 2009. First sampling of 27 military working dogs was done in the year 2008, but only 17 dogs were resampled next year. The sheepdogs were sampled in 2013 .

Blood samples for complete blood count (CBC) including white cell differential count determinations were collected into EDTAcontaining tubes (Microtainer TM, Beckton and Dickinson, Franklin Lakes, USA) by venipuncture of $v$. jugularis. For serologic testing, the blood was stored into serum separator tubes (Vacuette, Greiner Bio-One, Kremsmunster, Austria) and left for 30 minutes at room temperature to clot, then was centrifuged at $1300 \times \mathrm{g}$ for 10 minutes to separate the serum. Serum samples were analysed for antibodies to $M$. cynos, M. canis and M. molare.

Vaginal or prepuce and oral swabs for molecular detection of mycoplasma were collected with a sterile cotton swab (Sterile, Meus S.r.1., Piove di Sacco, Italy) and transported to the laboratory in a cold pack. The swabs were stored at $-70{ }^{\circ} \mathrm{C}$ until processing.

\section{Bacterial strains}

For DIBA type strains of M. cynos (strain H831 ${ }^{\mathrm{T}}$ ), M. canis (strain $\mathrm{PG} 14^{\mathrm{T}}$ ) and $M$. molare (strain $\mathrm{H} 542^{\mathrm{T}}$ ) were used as antigens. The mycoplasma strains were cultured on modified Frey`s medium described previously (15). For DIBA broth cultures were harvested by centrifugation $(20.000 \times \mathrm{g}$ for 10 min) before reaching the stationary growth phase. Mycoplasma cells were washed in phosphate buffered saline (PBS, pH 7.2) and diluted 1: 500 for DIBA.

\section{Blood analyses}

The haematological parameters were determined by an automated laser haematology analyser $\mathrm{H}^{*} 1$ (Siemens/Bayer (former Technicon), Munich, Germany) with species specific software $\left(\mathrm{H}^{*} 1\right.$ MultiSpecies V30 Software, Tarrytown, NY, USA).

\section{Dot-Immunobinding assay (DIBA)}

DIBA was used to determine antibodies against to $M$. cynos, $M$. canis and $M$. molare in dog serum samples as was previously described $(14,16$, 17). Briefly, two microliters of bacterial antigens, internal positive control (1:1000 diluted dog sera) and negative control (modified Frey`s medium) were dotted as separate dots on strips cut from PVDF membrane (Immobilon-P, Merck Millipore, Billerica, MA, USA). The strips were first blocked for one hour in $0.5 \%$ Tween 20 in PBS and then incubated in diluted $(1: 100)$ dog serum samples for one hour at room temperature, and after that washed three times for $15 \mathrm{~min}$ in PBS containing $0.05 \%$ Tween 20 . Then they were incubated in diluted (1:2000) rabbit anti-dog horseradish peroxidase conjugated (HRP) antibodies (catalogue number: A6792) (Sigma Aldrich, St. Louis, MO, USA) for $45 \mathrm{~min}$ at room temperature. After two 10-minute washes in PBS containing 0.05\% Tween 20 and one in PBS, strips were treated with 
chromogenic substrate TrueBlue ${ }^{\mathrm{TM}}$ (Kirkegaard and Perry Laboratories, Milford, MA, USA). Evaluation of DIBA results by personal estimation of the intensity of the blue color on the place of the reaction was done immediately after the test was finished.

\section{DNA extraction, PCR and sequencing}

Prior DNA extraction $2 \mathrm{ml}$ of sterile PBS was added to genital and oral swabs and vortexed vigorously. Total DNA was extracted using the commercial reagents of QIAamp ${ }^{\circledR}$ DNA Mini Kit (Qiagen, Hilden, Germany), according to the manufacturer's instructions.

For samples obtained in 2008 the semi-nested PCR for amplification of $1500 \mathrm{bp}$ long 16S rRNA gene described by Johansson (18) and colleagues was used. For samples obtained in 2009 and 2013 the PCR for amplification of approximately 620 bp long 16S/23S IGS region of different canine mycoplasma species were used (19). The extracted DNA of M. canis (strain PG14 ${ }^{\mathrm{T}}$ ) was used as positive control in the PCR assays.

The PCR products were analyzed by electrophoresis on a 1.8\% ethidium bromide stained agarose gel. DNA fragments were excised from the gel and purified with Wizard PCR Preps DNA Purification System (Promega, Madison, WI, USA) and sent for sequencing to Macrogen laboratory (Macrogen Inc, Amsterdam, the Netherlands).

The nucleotide sequences were downloaded using Chromas (Technelysium Pty Ltd., Queensland, Australia). Nucleotide sequence data were analyzed by BLAST (20) for finding similar nucleotide sequences from NCBI sequence database. Sequences with $\geq 99 \%$ nucleotide homology with available sequence in database were determined as mycoplasma species. In the cases of mixed sequencing chromatograms mixed mycoplasma infection (Mycoplasma spp.) was specified.

\section{Results}

\section{Animals}

Clinical examination prior sampling and haematological results for 34 dogs did not show any signs of diseases.

\section{DIBA analysis of canine blood serum}

DIBA test was used for simultaneous detection of specific antibodies against $M$. canis, $M$. cynos and $M$. molare. 34 dog serum samples were tested, 27 from military working dogs sampled in 2008 and 7 from sheepdogs taken in 2013 (Table 1). Specific antibodies against at least one of the mycoplasma species were detected in $32(94.1 \%)$ samples. Among them 8/34 (23.5\%) dogs were positive only to $M$. cynos, $7 / 34$ (20.6\%) dogs were positive only to $M$. canis and none of the samples were positive only to $M$. molare. On the other hand, $16 / 34$ (47.0\%) samples were positive to both $M$. cynos and $M$. canis and only one dog No 18 (2.9\%), had specific antibodies to all three mycoplasmas tested.

\section{PCR analysis and DNA sequencing results of canine swabs}

In 2008 18.5\% (5/27) swabs of different male military dogs were PCR positive, among these two oral $(7.4 \%)$ and 3 preputial swabs $(11.1 \%)$ (Table 1). As presented in Table 1 the analyses of partial sequences (680 to $1082 \mathrm{nt}$ ) of 16S RNA gene of positive samples from 2008 showed mixed mycoplasma infections in 2 preputial swabs (dogs No. 11,30 ) and 2 oral swabs (No. 16, 31). In one preputial swab dog No. 18 mixed infection with ureaplasma was detected.

Seventeen military dogs were sampled again in 2009. Six dogs (35.3\%) were positive, 5 genital swabs (29.4\%) and 1 oral swab (5.9\%). The prevalence of mycoplasmas in sheepdogs was $57.1 \%(4 / 7), 4$ oral swabs $(57.1 \%)$ and one genital swab (14.3\%). In female sheepdog No. 1 both oral and vaginal swabs were positive. The results of nucleotide sequence analysis of positive samples are shown in Table 1. M. cynos was confirmed in $20 \%(1 / 5)$ of positive oral swabs. $M$. canis was confirmed in $80 \%(4 / 5)$ of positive oral swabs. In positive genital swabs $(6 / 24), M$. canis was determined in $50 \%(3 / 6)$ cases, in one case together with $M$. spumans. $M$. edwardii and M. maculosum, were present in $16.7 \%$ of positive genital samples, not at the same time. In one case, in preputial swab of male dog no. 11, mixed not determined mycoplasma infection was confirmed as in the first testing at 2008. 
Table 1: Results of mycoplasmal DNA and specific antibodies screening in 34 working dogs using molecular PCR and serological method DIBA

\begin{tabular}{|c|c|c|c|c|c|c|c|}
\hline \multirow{2}{*}{$\begin{array}{l}\text { Dog } \\
\text { no. }\end{array}$} & \multirow{2}{*}{ Bread } & \multirow{2}{*}{ Gender } & \multirow{2}{*}{ Age* } & \multirow{2}{*}{ PCR **2008 } & \multirow{2}{*}{ PCR **2009/ 2013} & \multicolumn{2}{|c|}{ DIBA } \\
\hline & & & & & & M. canis & M. cynos \\
\hline 1 & TOR & $\mathrm{F}$ & $4 \mathrm{~m}$ & I & $\begin{array}{l}\text { M. edwardii (V), M. cynos } \\
\text { (O) }\end{array}$ & neg & pos \\
\hline 2 & TOR & M & $6 \mathrm{~m}$ & / & M. canis $(\mathrm{O})$ & pos & pos \\
\hline 3 & KSD & $\mathrm{F}$ & $6 \mathrm{~m}$ & / & neg & pos & pos \\
\hline 4 & KSD & M & 1 & / & M. canis $(\mathrm{O})$ & pos & pos \\
\hline 5 & KSD & M & 1 & / & M. canis $(\mathrm{O})$ & pos & pos \\
\hline 6 & TOR & $\mathrm{F}$ & 1 & / & neg & pos & pos \\
\hline 7 & TOR & $\mathrm{F}$ & 1 & l & neg & pos & neg \\
\hline 8 & GSD & M & 2 & neg & neg & pos & pos \\
\hline 9 & MN & M & 3 & neg & nd & pos & pos \\
\hline 10 & MN & M & 2 & neg & neg & pos & neg \\
\hline 11 & LR & M & 2 & Mycoplasma spp. (P) & Mycoplasma spp. (P) & neg & pos \\
\hline 12 & MN & M & 5 & neg & M. canis $(\mathrm{P})$ & pos & pos \\
\hline 13 & MN & M & 7 & neg & nd & pos & neg \\
\hline 14 & MN & M & 2 & neg & M.canis. (P) & pos & neg \\
\hline 15 & MN & M & 3 & neg & nd & pos & neg \\
\hline 16 & LR & M & 2 & Mycoplasma spp. (O) & nd & neg & pos \\
\hline 17 & $\mathrm{X}$ & $\mathrm{F}$ & 4 & neg & M. canis, M.spumans (V) & neg & pos \\
\hline 18 & MN & $\mathrm{M}$ & 7 & Ureaplasma spp. (P) & nd & pos & pos \\
\hline 19 & MN & M & 10 & neg & neg & pos & neg \\
\hline 20 & GSD & $\mathrm{F}$ & 5 & neg & M. maculosum (V) & neg & neg \\
\hline 21 & MN & M & 6 & neg & nd & neg & pos \\
\hline 22 & MN & M & 5 & neg & neg & neg & pos \\
\hline 23 & GSD & M & 4 & neg & neg & pos & neg \\
\hline 24 & GSD & $\mathrm{F}$ & 5 & neg & M. canis $(\mathrm{O})$ & pos & pos \\
\hline 25 & GSD & M & 7 & neg & neg & pos & pos \\
\hline 26 & GSD & M & 3 & neg & neg & neg & neg \\
\hline 27 & MN & M & 2 & neg & neg & pos & pos \\
\hline 28 & GSD & M & 9 & neg & neg & pos & pos \\
\hline 29 & MN & M & 4 & neg & nd & pos & pos \\
\hline 30 & GSD & M & 7 & Mycoplasma spp. (P) & nd & pos & pos \\
\hline 31 & MN & M & 2 & Mycoplasma spp. (O) & nd & pos & pos \\
\hline 32 & GSD & M & 4 & neg & neg & neg & pos \\
\hline 33 & MN & $\mathrm{F}$ & 3 & neg & neg & neg & pos \\
\hline 34 & MN & $\mathrm{M}$ & 2 & neg & nd & pos & pos \\
\hline
\end{tabular}

Dog numbers 1-7 present samples of sheepdogs, dog numbers 8-34 present samples of military dogs. *age at first sampling, m month; ** year of the sampling; TOR Tornjak- Bosnian and Herzegovininan- Croatian shepherd dog; KSD Karst shepherd dog; GSD German shepherd dog; LR labrador retriever; X mixed breed; MN Malinois; O oropharyngeal swab; P preputial swab; V vaginal swab, nd not done. 


\section{Discussion}

This is the first extended mycoplasma detection study in healthy working dogs where mycoplasma specific antibodies and molecular mycoplasma detection from oral and genital samples were included. Rare studies were done regarding the prevalence of mycoplasmas in dogs $(3,5,8,21)$ and there is no published data regarding seroprevalence of mycoplasma infections in healthy dogs. In a previous study, where diseased and healthy dogs were included, the haemagglutination-inhibition (HI) assay revealed $\sim 47 \%$ of dogs with antibodies to $M$. cynos (13). The HI assay is very specific but may be influenced by $M$. cynos strain causing infection and its strain used as HA antigen. In this study for simultaneous detection of specific antibodies against dog mycoplasmas $M$. cynos, $M$. canis and $M$. molare DIBA was used as a serological test. The presence of specific antibodies was confirmed in $32 / 34(94 \%)$ tested samples, at least against one species of mycoplasma in question. With regard to previous studies, where Doig and others (8) reported $33.3 \%$ to $76.19 \%(16 / 21)$ prevalence of $M$. canis in mycoplasma positive genital swabs and Chalker and others (6) found $21.8 \%$ prevalence in oral swabs of healthy dogs, we can speculate that such high number of positive reactions to $M$. canis and $M$. cynos antigens in our study is probably the result of cross reactivity between different mycoplasmas. Despite the simplicity of DIBA the main disadvantage is that the evaluation of the test is based on subjective decisions and that is why it is sometimes hard to define the intensity of the reaction with specific antigens. This could be avoided using densitometry that can provide a quantitative evaluation of the result (23, 24). Regarding high serological prevalence in tested dogs, antibody titer determination and demonstration of increased antibody titer two to three weeks apart should be performed to establish the criteria for confirmation of acute onset of infection.

With PCR method and sequencing, the presence of mycoplasmas was detected in $57.1 \%(4 / 7)$ of younger dogs ( $\leq 1$ year) and in $33.3 \%(9 / 27)$ of older dogs. It has been reported that the infection with mycoplasmas is more common in young dogs than in older ones (5). In 2008 mycoplasma and ureaplasma were confirmed only in male dogs whereas the prevalence of mycoplasmas was higher $50 \%(4 / 8)$ in females compared with $37.5 \%$ (6/16) in males sampled in 2009 and 2013. Genital swabs were positive in $60 \%(9 / 15)$ cases and oral in $46.7 \%(7 / 15)$ cases. In the study by Rosendal (22) on healthy dogs, mycoplasmas were detected in all naso-oro-pharyngeal cavity and in 70 to $75 \%$ cases of genital samples. Very high prevalence $(86.7 \%)$ of mycoplasmas in upper respiratory tract of dogs without respiratory signs was reported by Schulz and others (25). These results coincide with our results, where $94 \%$ of the tested dogs were seropositive. On the contrary, Hong and Kim (21) detected mycoplasma only in diseased $\mathrm{dog}$ in a group of laboratory dogs. Similarly, to our study, the detection was done by molecular methods directly from clinical samples without previous isolation of the mycoplasma, while in studies mentioned above $(22,25)$ isolation of bacteria was performed. The difference between results in different studies is probably also due to the different health background of included dogs; from dogs that were euthanized because of other diseases (25) to laboratory dogs (21). Dogs included in this study were healthy, without any history of respiratory infections or reproductive problems. The good general health status of the dogs could influence the lower mycoplasma presence. In one case, M. cynos, and in three cases, $M$. canis, were simultaneously confirmed by PCR and by serology. Although positive serology results in this study indicate exposure to mycoplasma in the past, it is also possible than an undetectable quantity of mycoplasma is present in mucosa and affects serology results. Unfortunately, because of the small number of samples in our study, it is difficult to compare the results with other studies where a larger number of dogs was included.

As is the case in other studies $(6,8)$, we confirmed that $M$. canis is one of the most common mycoplasma species present in dogs. In our study, altogether, $M$. canis was detected in $46.7 \%(7 / 15)$ mycoplasma-positive dogs. We obtained $33.3 \%$ (1/3) prevalence of $M$. canis in positive vaginal swab and $40 \%(2 / 5)$ prevalence of $M$. canis in mycoplasma positive preputial swabs. In positive oral swabs $M$. canis was confirmed in $57.1 \%(4 / 7)$. As was mentioned earlier, for true estimation of prevalence a larger number of dogs should be tested. Second most common mycoplasma infection was mixed infection. Infections with at least 2 Mycoplasma species (usually M. cynos and M. canis) in $42.9 \%$ of bitches with no clinical signs 
or any other disturbances in reproduction cycle and in $13.3 \%$ prepuce swabs of healthy male dogs with at least two mycoplasmas were confirmed by Doig and others (8) in previous study. We found mixed infection in $33.3 \%(1 / 3)$ positive vaginal swabs and in $83.3 \%(5 / 6)$ mycoplasma or ureaplasma positive preputial swabs. The mixed infection was detected also in $28.6 \%(2 / 7)$ positive oral swabs. In one case (dog no. 17) mycoplasma species were determined successfully, in all other cases with mixed infection PCR cloning should be done.

Despite the differences between the seropositive results and positive PCR samples, PCR is a suitable method for fast diagnostics, but application of consensus primers for clinical samples should not be the method of choice. The main disadvantages are nonspecific positive reactions and in case of mixed infections the pathogen species can be masked by others. Based on known data obtained in previous studies the use of species specific primers would make this diagnostic method more suitable for routine use $(6,21)$. In cases when direct detection of pathogen fails, serology can help with diagnostics. After optimization of the method, DIBA could be included in the routine clinical practice as a screening serological test.

Despite several studies, comprehensive data about mycoplasma presence in dogs is missing. Since data about prevalence of mycoplasmas in different studies is controversial, regardless of the method of detection (PCR or culture) or chosen group of dogs, further studies should be done to accurately evaluate positive results, also in the context of pathogenicity of canine mycoplasmas.

\section{Acknowledgement}

This study was financially supported by Slovenian Research Agency, program group P40092. The authors would like to thank Urša Ravnik Verbič for helping with the sampling, Aleksander Jenko for technical support in the laboratory and all dog owners for participation.

\section{References}

1. Razin S, Yogev D, Naot Y. Molecular biology and pathogenicity of mycoplasmas. Microbiol Mol Biol Rev 1998; 62: 1094-156.

2. Rosengarten $\mathrm{R}$, Citti C, Glew $\mathrm{M}$, et al.
Host-pathogen interactions in mycoplasma pathogenesis:virulence and survival strategies of minimalist prokaryotes. Int J Med Microbiol 2000; 290(1): 15-25.

3. Chalker VJ. Canine mycoplasmas. Res Vet Sci 2005; 79: 1-8.

4. Spergser J, Langer S, Muck S, et al. Mycoplasma mucosicanis $s p$. nov., isolated from the mucosa of dogs. Int J Syst Evol Microbiol. 2011; 61(4): 716-21.

5. Randolph JF, Moise NS, Scarlett JM, et al. Prevalence of mycoplasmal and ureaplasmal recovery from tracheobronchial lavages and prevalence of mycoplasmal recovery from pharyngeal swab specimens in dogs with or without pulmonary disease. Am J Vet Res 1993; 54: 387-91.

6. Chalker VJ, Owen WMA, Paterson C, et al. Mycoplasma associated with canine infectious respiratory disease. Microbiology 2004; 150: 3491-7.

7. Rycroft AN, Tsounakou E, Chalker V. Serological evidence of Mycoplasma cynos infection in canine infectious respiratory disease. Vet Microbiol 2007; 120: 358-62.

8. Doig PA, Ruhnke HL, Bosu WT. The genital mycoplasma and ureaplasma flora of healthy and diseased dogs. Can J Comp Med 1981; 45: 233-8.

9. Ülgen M, Cetin C, Sentürk S, et al. Urinary tract infections due to Mycoplasma canis in dogs. J Vet Med A Physiol Pathol Clin Med 2006; 53: 379-82.

10. Waites KB, Xiao L, Paralanov V, Viscardi RM, Glass JI. Molecular methods for the detection of Mycoplasma and ureaplasma infections in humans: a paper from the 2011 William Beaumont Hospital Symposium on molecular pathology. J Mol Diagn. 2012; 14(5): 437-50.

11. Busolo F, Tonin E, Conventi L. Enzyme-linked immunosorbent assay for detection of Mycoplasma pneumoniae antibodies. J Clin Microbiol 1980; 12: 69-73.

12. Kumar A, Srivastava NC, Singh VP, et al. Electrophoretic analysis of indian isolates of $\mathrm{My}$ coplasma agalactiae and Mycoplasma bovis by SDS - PAGE and immunoblotting. Vet Med Int 2014; 2014: e892421 http://www.ncbi.nlm.nih. gov/pmc/articles/PMC3998006/ (5. 7. 2014)

13. Kastelic S, Cizelj I, Narat M, et al. Molecular characterisation of the Mycoplasma cynos haemagglutinin HapA. Vet Microbiol 2015; 30; 175(1): 35-43.

14. Benčina $M$, Cizelj I, Berčič RL, Narat M, Benčina D, Dovč P. Shared epitopes of avian im- 
munoglobulin light chains. Vet Immunol Immunopathol. 2014; 158(34): 175-81.

15. Berčič RL, Cizelj I, Benčina $M$, Narat $M$, Bradbury JM, Dovč P, Benčina D. Demonstration of neuraminidase activity in Mycoplasma neurolyticum and of neuraminidase proteins in three canine Mycoplasma species. Vet Microbiol 2012; 155(2/4): 425-9.

16. Narat M, Biček A, Vadnjal R, Benčina D. Production, characterization and use of monoclonal antibodies recognizing IgY epitopes shared by chicken, turkey, pheasant, peafowl and sparrow. Food Technol Biotechnol 2004; 42(3): 175-82.

17. Benčina $\mathrm{D}$, Narat $\mathrm{M}$, Bidovec A, Zorman-Rojs O. Transfer of maternal immunoglobulins and antibodies to Mycoplasma gallisepticum and Mycoplasma synoviae to the allantoic and amniotic fluid of chicken embryos. Avian Pathol 2005; 34(6): 463-72.

18. Johansson KE, Heldtander MU, Pettersson B. Characterization of mycoplasmas by PCR and sequence analysis with universal 16S rDNA primers. Methods Mol Biol. 1998; 104: 45-65.

19. Chalker VJ, Brownlie J. Taxonomy of the canine Mollicutes by 16S rRNA gene and 16S/23S
rRNA intergenic spacer region sequence comparison. Int J Syst Evol Microbiol 2004; 54: 537-42.

20. Altschul SF, Gish W, Miller W, Myers EW, Lipman DJ. Basic local alignement search tool. J Mol Biol 1990; 215: 403-10.

21. Hong S, Kim O. Molecular identification of Mycoplasma cynos from laboratory beagle dogs with respiratory disease. Lab Anim Res 2012; 28: 61-6.

22. Hawkes R, Niday E, Gordon J. A dot-immunobinding assay for monoclonal and other antibodies. Anal Biochem 1982; 119: 142-7.

23. Furuya K, Noro S, Yamagishi T, et al. Adsorption of influenza viruses to nitrocellulose membrane filters by filtration and their quantitative densitometric determination. J Virol Methods 1984; 9: 193-9.

24. Rosendal S. Canine mycoplasmas: their ecologic niche and role in disease. J Am Vet Med Assoc 1982; 180: 1212-4.

25. Schulz BS, Raufeisen K, Weber K, Laberke $\mathrm{S}$, Hartmann K. Comparison of the prevalence of Mycoplasma species in dogs with and without respiratory disease. Berl Munch Tierarztl Wochenschr. 2015; 128(7/8): 304-9.

\title{
MOLEKULARNA DETEKCIJA IN SEROPREVALENCA MIKOPLAZEM PRI KLINIČNO ZDRAVIH DELOVNIH PSIH
}

\author{
S. Suhadolc Scolten, N. Tozon, S. Koprivec, K. Felda, M. Florjančič, D. Benčina, B. Slavec
}

Povzetek: Namen raziskave je bil določiti seroprevalenco in prevalenco mikoplazem pri klinično zdravih delovnih psih. V raziskavo je bilo vključenih 34 delovnih psov različnih pasem in starosti, od tega 27 psov iz Slovenske vojske in 7 ovčarskih psov. Za dokazovanje specifičnih protiteles proti bakterijam Mycoplasma cynos, Mycoplasma canis in Mycoplasma molare smo uporabili metodo točkastega imunskega odtisa (ang. Dot Immuno Binding Assay-DIBA) in konvencionalni PCR, ki temelji na pomnoževanju odseka gena za ribosomalno RNK 16s ali intergenskega odseka genoma med genoma ribosomalnih RNK 16s in 23s. Specifična protitelesa proti vsaj eni od izbranih vrst mikoplazem so bila ugotovljena pri $94.1 \%$ psov. Med njimi je $23.5 \%$ vzorcev reagiralo pozitivno samo na M. canis, 20.6 \% samo na M. canis in noben od vzorcev ni reagiral pozitivno samo na M. molare. Skupno je $47.0 \%$ vzorcev reagiralo pozitivno na M. canis in M. canis hkrati, en pes (2.9\%) je imel specifična protitelesa proti vsem trem testiranim mikoplazmam. Z metodo PCR smo mikoplazme dokazali v vzorcih $57.1 \%$ psov mlajših od enega leta, in pri $18.5 \%$ do $35.3 \%$ starejših od enega leta, odvisno od leta vzorčenja. Genitalni brisi so bili pozitivni v 60 \% primerov v primerjavi z oralnimi kjer je bil delež $46.7 \%$. M. canis je bila ugotovljena v $40 \%$ pozitivnih primerov, v enakem deležu so bile ugotovljene tudi mešane nedeterminirane mikoplazemske okužbe. Mikoplazme, kot so M. cynos, M. edwardii. M. maculosum in M. spumans so bile ugotovljene posamično. Venem primeru je bila ugotovljena mešana okužba z ureaplazmami.

Ključne besede: delovni psi; pasje mikoplazme; Mycoplasma canis; Mycoplasma cynos; DIBA; PCR 